\title{
Quantitative paleoparasitology applied to archaeological sediments
}

\begin{abstract}
Martín H Fugassa ${ }^{+}$, Adauto Araújo*, Ricardo A Guichón**
Departamento de Biología, Facultad de Ciencias Exactas y Naturales, Universidad Nacional de Mar del Plata, calle Funes 3350, Mar del Plata (7600), Buenos Aires, Argentina *Escola Nacional de Saúde Pública-Fiocruz, Rio de Janeiro, RJ, Brasil **Departamento de Biología, Universidad Nacional de Mar del Plata y Universidad Nacional del Centro, Buenos Aires, Argentina

Three techniques to extract parasite remains from archaeological sediments were tested. The aim was to improve the sensibility of recommended paleoparasitological techniques applied in archaeological remains. Sediment collected from the pelvic girdle of a human body found in Cabo Virgenes, Santa Cruz, Argentina, associated to a Spanish settlement founded in 1584 known as Nombre de Jesús, was used to search for parasites. Sediment close to the skull was used as control. The techniques recommended by Jones, Reinhard, and Dittmar and Teejen were used and compared with the modified technique presented here, developed to improve the sensibility to detect parasite remains. Positive results were obtained only with the modified technique, resulting in the finding of Trichuris trichiura eggs in the sediment.
\end{abstract}

Key words: archaeological sediments - parasite remains - Trichuris eggs - archaeological sediment technique paleoparasitology - Southern Patagonia

Life in the past can be reconstructed by applying different tools of science to understand ancient events. Combined, these tools offer well sustainable data to base and test hypothesis as they are obtained from different fields of science (Walker 1996). The study of bioanthropology in Southern Patagonia has the contribution of History, Archaeology, Anthropology, and Biology. Paleoparasitology emerged as a branch of Paleopathology and aims the study of parasites found in archaeological and paleontological material. Parasites have been found in coprolites, latrine sediments, mummified tissues, hairs, and many other organic remains (Bouchet et al. 2003a). Sediment associated with skeletons has been less explored than other organic remains in the search for parasites. Latrine and soil sediment recovered from latrines and soil occupied by ancient human populations are the most common examined and studied material (Pike 1968, Moore 1981, Bouchet 1995, Bouchet et al. 1999, 2002, Taek Han et al. 2003, Fernandes et al. 2005); shell middens (Bathurst 2005), artifacts (Harter et al. 2003), and skeleton remains (Aspöck et al. 1996, Bouchet et al. 2001, Dittmar \& Teejen 2003) are less studied. Parasite remains are supposed to disperse and be lost in sediments. This is the case of Patagonian steppe sandy sediments submitted to hydric and thermal environmental conditions influencing parasite egg preservation in the soil.

Otherwise, sediment collected inside skeletons may offer opportunities to assay paleoepidemiological studies. Skeletons are more commonly found than coprolites,

Financial support: Conicet, SECyT/Capes, CNPq, Universidad Nacional de Mar del Plata

${ }^{+}$Corresponding author: mfugassa@mdp.edu.ar

Received 20 July 2006

Accepted 16 October 2006 and sex and age can be more easily inferred. Therefore, associated with calibrated dating and well archaeologically and geographically located, skeletons allow obtaining data to associate parasite findings with the human host. Population studies may be approached as far as more skeletons are analyzed.

Sediments have been analyzed with paleoparasitological techniques, modified from Stoll technique (Jones 1988, Taek Han et al. 2003), spontaneous sedimentations (Faulkner et al. 2000, Fernandes et al. 2005), sedimentation-flotation (Bouchet 1995, Bouchet et al. 1999, 2001), and combining sedimentation and palynological technique (Reinhard et al. 1992, Dittmar \& Teejen 2003). To understand and interpret correctly parasite finds in sediments of each locality of an archaeological site careful analysis is needed (Reinhard 1988). Even though, to better understand the meaning of parasite finds in archaeological sites frequencies must be achieved comparing parasite finds. Therefore, the study of parasites in archaeological sediments requires the use of quantitative techniques to compare the findings of parasites in different samples and controls.

We strongly reinforce that this kind of archaeological deposit is very important and the data obtained can be improved combining careful sediment in situ extraction method with quantitative paleoparasitological techniques adapted to this kind of material. We have tested techniques used and recommend a slight modification that improves significantly parasite analysis in organic sediments. All tests were performed with Southern Patagonian samples, which were submitted to characteristic environmental conditions.

\section{MATERIALS AND METHODS}

The archaeological site Nombre de Jesús was recorded by Senatore and Guichón in 2005 (Guichón, pers. commun.). The burial site is under open sky. The site corresponds to the first Spanish attempts to colonize the 
Magellan Strait during the XVI century. In 1584 Sarmiento de Gamboa finally established the first settlings called Rey Felipe in the west coast, and Nombre de Jesús in the east, southern of Virgins Cape, Argentina (Fig. 1).

An Indian skeleton was found in 2004 dated of $475 \pm$ $45 \mathrm{yr}$ BP (Ua 22946). Another three skeletons in the same burial place were found during 2005 excavations. They were identified as of Europeans. Excavation was planned to recover burial samples following Jones (1988), Reinhard et al. (1992), and Berg (2002). Pelvic girdle and sacroccocygeal samples were collected. Control samples were collected from skull and the thighbone regions. Only results of the individual NJ-4 corresponding to the finds of the year 2005 are presented here (Fig. 2).

Sediments were rehydrated in trisodium phosphate $0.5 \%$ aqueous solution (Callen \& Cameron 1960). Quantitative techniques applied in paleoparasitology were used. According to Jones (1982), $3 \mathrm{~g}$ of dry sediment were rehydrated in $42 \mathrm{ml}$ of trisodium phosphate $0.5 \%$ aqueous solution. Five samples of the same material were made. A 50 $\mu l$ drop of rehydrated sample was used to prepare ten slides to microscopic analysis. Reinhard et al. (1992) quantitative sedimentation technique was also tested, adding Lycopodium tablets containing known quantities of spores (12542 spores). Counting spores and parasite eggs allow calculating how many eggs are in each gram of feces [(eggs counted/spores counted $)^{*} 12542 /$ sediment weight $=$ eggs parasites by g sediment $]$.

Jones modified technique consists in increasing six times sediment concentration due to the high quantity of

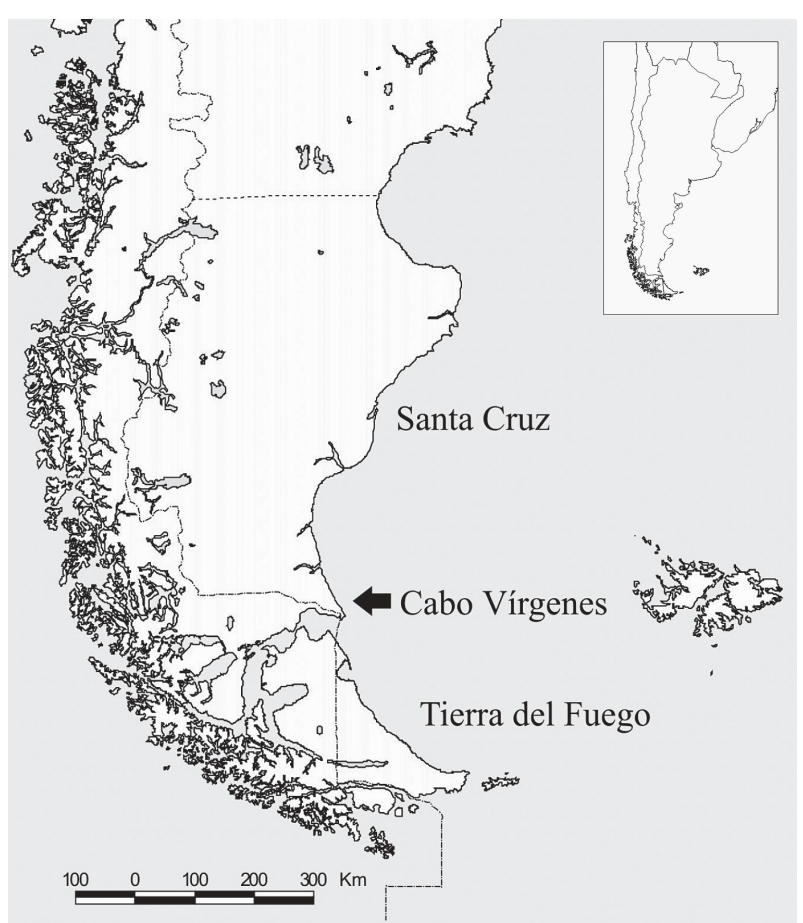

Fig. 1: geographical localization of Nombre de Jesús archaeological site.

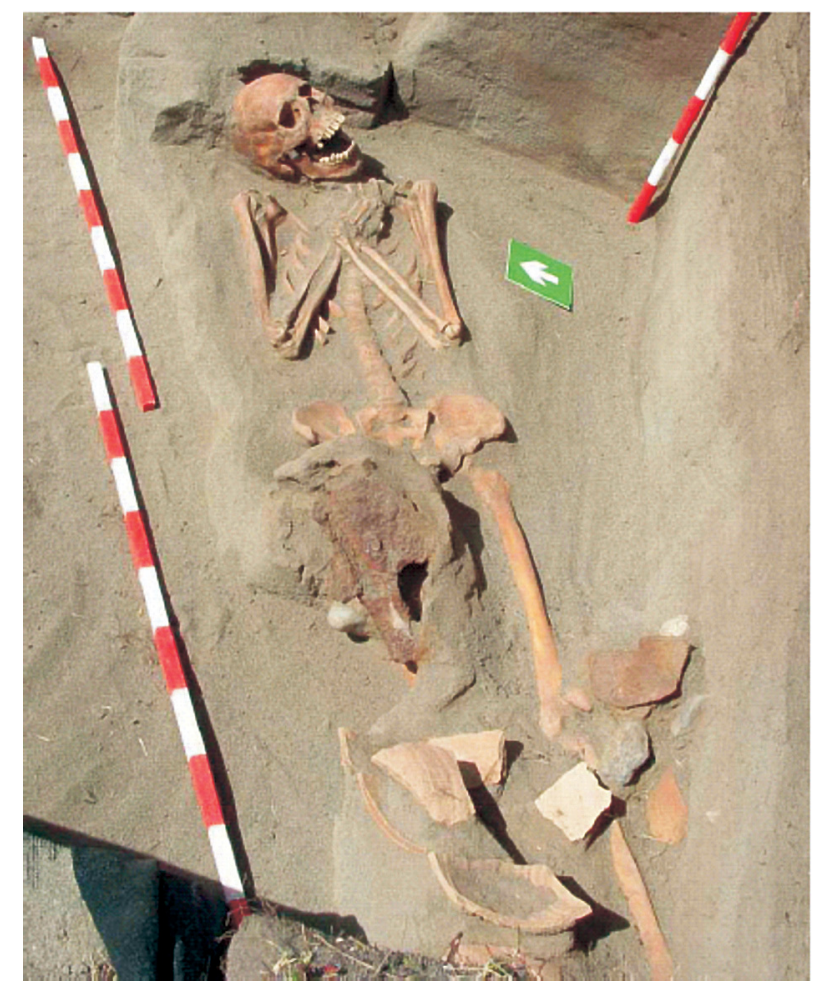

Fig. 2: burial human remains of Nombre de Jesús archaeological site, Cabo Vírgenes, Santa Cruz, Argentina.

sand in the sediment. Five preparations were made for each sample, each one of $5 \mathrm{~g}$ of the sediment in $10 \mathrm{ml}$ of $0.5 \%$ trisodium phosphate solution. Fifty slides were prepared of each sample using $50 \mu 1$ drops of shacked and mixed solution and observed at the microscope. Macroscopic hard concretions were observed in one sample.

\section{RESULTS}

Using recommended techniques no parasite eggs were found. Positive results were only obtained in the sediment collected in the pelvic girdle of the skeleton using Jones modified technique. Trichuris sp. (Fig. 3) eggs were recovered, with average measurements of $53.25 * 27.87$ $\mu \mathrm{m}$ (range 46.25-62.5*25-32.5 $\mu \mathrm{m}$ ), with a concentration of $5.1 \mathrm{eggs} / \mathrm{g} /$ feces.

Poorly preserved parasite eggs were also found (Fig. 4) but could not be identified. Free-living adult nematodes and abundant fungal structures were recovered using Jones modified technique, which was used to examine both the sediment collected from the pelvic girdle, sacroccocygeal, and the control (skull). Positive results contrasted with the control sediment where no parasites were found. Low concentration of fungal spores was also found in the skull sediment.

\section{DISCUSSION}

First paleoparasitological sediment analysis was performed by spontaneous sedimentation in two Indian skeletons in the same archaeological region of Southern Patagonia, Argentina (Fugassa et al. 2004). Both were negative for parasites. Further tests are needed, but results 


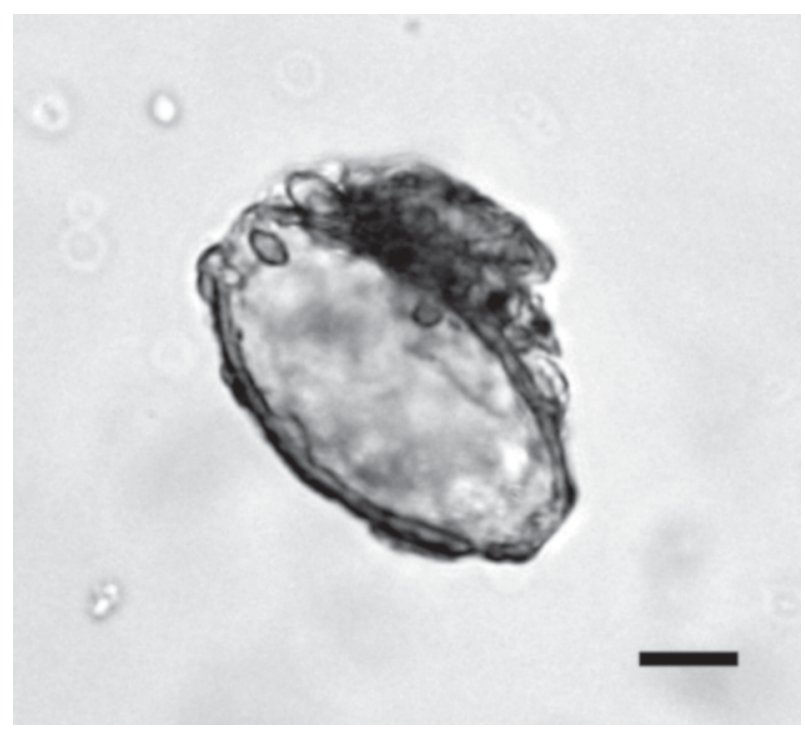

Fig. 3: Trichuris sp. egg found in the skeleton pelvic girdle of the archaeological site of Cabo Vírgenes, Santa Cruz, Argentina. Bar: $10 \mu$. with the modified technique presented here are promising, especially for sediments submitted to high percolation, thermal and chemical stress, and high sand concentration.

Bouchet et al. (2003a) have advised that the technique developed by Jones is sensible for egg concentration higher than 400 eggs/g/feces. For this reason, increased dilution concentration was tried resulting in positive parasite findings.

Morphometric parameters of Trichuris eggs found correspond to those of T. trichura (Thienpont et al. 1978). Other Trichuris species found in hosts of the region have different egg dimensions (Table). Only T. pampeana has close egg measurements to T. trichiura. However, the rodent host, Ctenomys azarae, is found exclusively in the extreme northern part of Patagonia (Olrog \& Lucero 1981). Rodent feces are also easily identified (Chame 2003).

Fragmented structures resembling Ascaris sp. eggs were found. Although no definitive diagnosis could be achieved, the association $A$. lumbricoides/T. trichura was very common for the same period in Europe (Bouchet et al. 2003b, Fernandes et al. 2005). The relation A. lum-
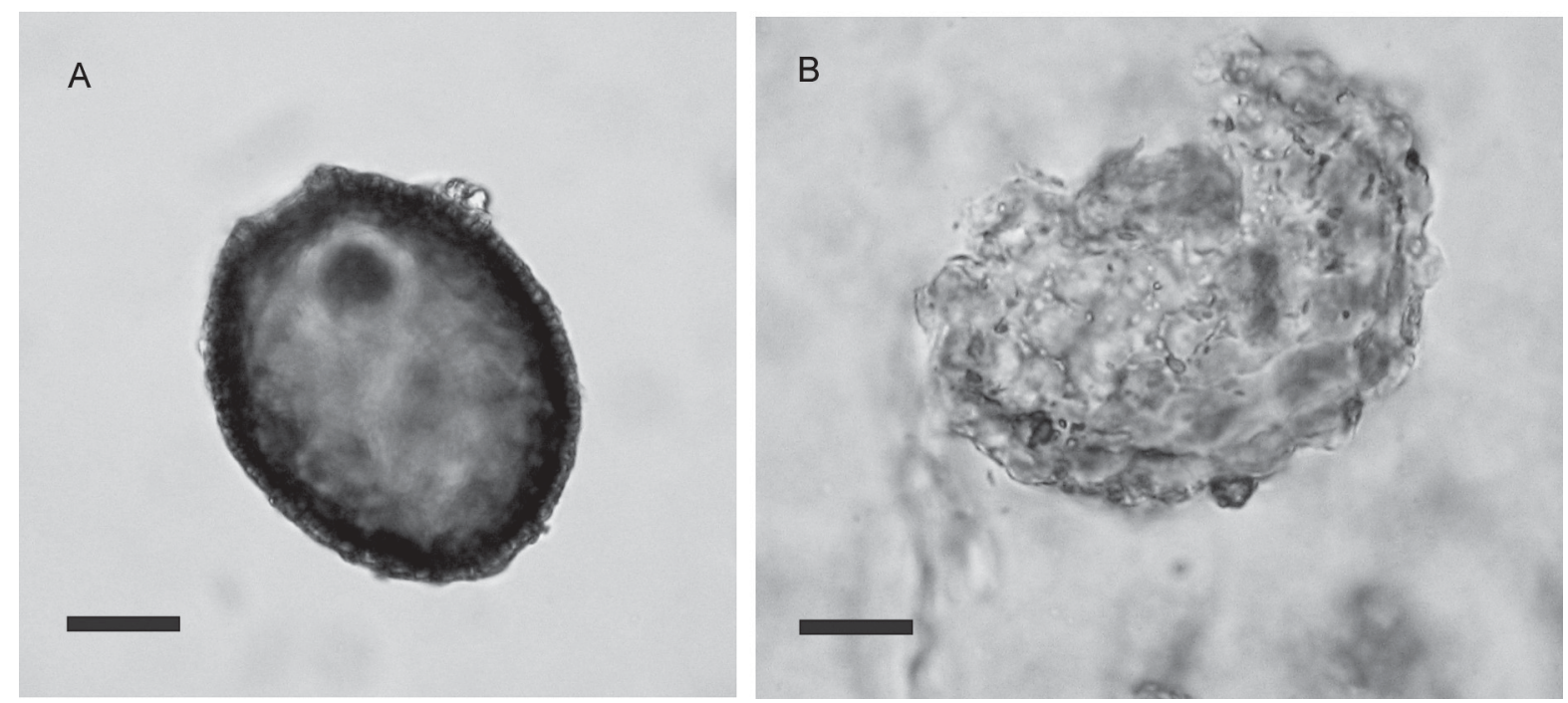

Fig. 4: parasite organic organic remains with no confirmed diagnosis. A: operculated egg; B: Ascaris sp. egg-like. Bars: $20 \mu$.

TABLE

Trichuris species recorded in Patagonian rodent and camelid species

\begin{tabular}{llccl}
\hline Host & Species & Lenght $(\mathrm{m})$ & Width $(\mathrm{m})$ & Reference \\
\hline Lama guanicoe & Trichuris sp. & 79 & 32 & Beldomenico et al. (2003) \\
& T. tenuis a & $46-50$ & $28-30$ & \\
Octodon sp. & T. bradleyi & $57-65$ & $29-34$ & Babero et al. (1975) \\
Ctenomys sp. & T. fulvis & $65-72$ & $28-31$ & Babero \& Murua (1987) \\
& T. robusti & $57-65$ & $29-36$ & Babero \& Murua (1990) \\
& T. bursacaudata & $60-70$ & $20-30$ & Suriano \& Navone (1994) \\
Akodon sp. & T. pampeana & $50-60$ & $20-30$ & \\
Myocastor coipus & T. chilensis & $60-67$ & $32-34$ & Babero et al. 1976 \\
Dolichotis patagonum & T. myocastoris & $53-60$ & $30-34$ & Baró et al. (1975) \\
a. dolichotis & 75 & 45 & Morini et al. (1955)
\end{tabular}

$a$ : reported measurement by Chandler 1930 . 
bricoides and T. trichiura recorded for the European sites was 1:3 (Moore 1981) and 1:6 (Jones 1982). Therefore, if these proportions are correct, and taken into account that a density of $5.1 \mathrm{eggs} / \mathrm{g} / \mathrm{feces}$ was obtained for T. trichiura, the probability of finding $A$. lumbricoides eggs is very low, using optical microscopy and the methodology described here. However, human roundworm and whipworm association is so common that $A$. lumbricoides/T. trichiura eggs is the probable diagnosis in this case.

All samples were positive for T. trichiura. The reduced number of fungi hyphae and spores in the control sample, in contrast with the pelvic sediment with no parasite eggs evidence the expected decomposition of intestinal region of the body until partially preservation of organic remains was completed. Controls add comparative critic information to know the origin of the material studied (Reinhard et al. 1992).

To conclude, combining systematic bioarchaeological and adapted paleoparasitological techniques allow interesting results regarding parasite findings in the less expected organic remains where parasites are recorded. It is important to note that parasitism is a natural phenomenon, and some parasite species accompany humans throughout the continents since the species arises in African landscapes (Araújo et al. 2003, Montenegro et al. 2006).

\section{ACKNOWLEDGMENTS}

To Dr Denegri, Dr Sardella, and Dr Burry, Universidad Nacional de Mar del Plata; Dr Ximena Senatore and Dr Luis A Borrero (Conicet-Dipa-IMHICIHU).

\section{REFERENCES}

Araújo A, Jansen AM, Bouchet F, Reinhard K, Ferreira LF 2003. Parasitism, the diversity of life, and paleoparasitology. Mem Inst Oswaldo Cruz 98 (Suppl. 1): 5-11.

Aspock H, Auer H, Picher O 1996. Trichuris trichiura eggs in the Neolithic glacier mummy from the Alps. Parasitol Today 12: 255-256.

Babero BB, Murua R 1987. The helminth fauna of Chile. X. A new species of whipworm from a Chilean rodent. Trans Am Microbiol Soc 106: 190-193.

Babero BB, Murua R 1990. A new species of whipworm from South American hystricomorph rodent. Mem Inst Oswaldo Cruz 85: 211-213.

Babero BB, Cattan PE, Cabello C 1975. Trichuris bradleyi sp. n., a whipworm from Octodon degus in Chile. J Parasitol 61: 1061-1063.

Babero BB, Cattan PE, Cabelo C 1976. A new species of whipworm from the rodent Akodon longipilis in Chile. Trans Am Microbiol Soc 95: 232-235.

Barós V, Majumdar G, Mikailov TK 1975. Morphology ad taxonomy of Trichocephalus myocastoris (Enigk, 1933). Folia Parasitol 22: 207-213.

Bathurst RR 2005. Archaeological evidence of intestinal parasites from coastal shell middens. J Archaeol Sci 32: 115123.

Berg GE 2002. Last meals: recovering abdominal contents from skeletonized remains. J Archaeol Sci 29: 1349-1365.

Bouchet F 1995. Recovery of helminth eggs from archaeological excavations of the Grand Louvre (Paris, France). J Parasitol 80: 785-787.

Bouchet F, Guidon N, Dittmar K, Harter S, Ferreira LF, Chaves SM, Reinhard KJ, Araujo A 2003a. Parasite remains in archaeological sites. Mem Inst Oswaldo Cruz 98 (Suppl. I): 47-52.

Bouchet F, Harter S, Le Bailly M 2003b. The state of the art of paleoparasitology research in the Old World. Mem Inst Oswaldo Cruz 98 (Suppl. I): 95-102.

Bouchet F, Harter H, Paicheler JC, Araujo A, Ferreira LF 2002. First recovery of Schistosoma mansoni eggs from a latrine in Europe (15-16th centuries). J Parasitol 88: 404-405.

Bouchet F, Lefevre C, West D, Corbett D 1999. First paleoparasitological analysis of the midden in the Aleutian islands (Alaska): results and limits. J Parasitol 85: 369-372.

Bouchet F, West D, Lefevre C, Corbett D 2001. Identification of parasitosis in a child burial from Adak island (Central Aleutian Islands, Alaska). Life Sciences 324: 123-127.

Callen EO, Cameron TWM 1960. A prehistoric diet revealed in coprolites. New Scientist 8: 35-40.

Chame M 2003. Terrestrial mammal feces: a morphometric summary and description. Mem Inst Oswaldo Cruz 98 (Suppl. I): 71-94.

Dittmar K, Teejen W 2003. The presence of Fasciola hepatica (liver fluke) in human and cattle from a 4500 years old archaeological site in the Saale-Unstrut Valley, Germany. Mem Inst Oswaldo Cruz 98 (Suppl. I): 141-144.

Faulkner ChT, Cowie SE, Martin PE, Martin SR, Mayes CS, Patton SH 2000. Archaeological evidence of parasitic infection from the 19th century company town of Fayette, Michigan. J Parasitol 86: 846-849.

Fernandes A, Ferreira LF, Gonçalves ML, Bouchet F, Klein $\mathrm{CH}$, Iguchi T, Sianto L, Araújo A 2005. Intestinal parasite analysis in organic sediments collected from a 16th-century Belgian archaeological site. Cad Saúde Públ 21: 329-332.

Fugassa MH, Guichón RA, Denegri GM, Sardella NH, Senatore MX 2004. Análisis cuantitativo de restos de enteroparásitos en un sitio arqueológico de Patagonia Austral. Actas XV Congreso Nacional de Arqueología Argentina, Río Cuarto, Córdoba.

Harter S, Le Bailly M, Janot F, Bouchet F 2003. First paleoparasitological study of an embalming rejects jar found in Saqqara, Egypt. Mem Inst Oswaldo Cruz 98 (Suppl. I): 119-121.

Jones AKG 1982. Recent finds of intestinal ova at York, England. Proc Paleopathol As. 4th European Meeting, Middelburg, Antwerpen, p. 7.

Jones AKJ 1988. Collecting samples from human remains: the perspective of an environmental archaeologist. Arch-Form Newsl 2: 8-11.

Moore PD 1981. Life seen from a medieval latrine. Nature 294(17): 614 .

Montenegro A, Araujo A, Eby M, Ferreira LF, Hetherington R, 
Weaver AJ 2006. Parasites, paleoclimate, and the peopling of the Americas using hookworm to time Clovis migration. Cur Anthropol 47: 193-200.

Morini EG, Boero JJ, Rodríguez A 1955. Parásitos intestinales en el "mara" (Dolichotis patagonum patagonum). Misión de Estudios de Patología Regional Argentina 26: 83-89.

Olrog CC, Lucero N 1981. Guía de los Mamíferos Argentinos, Fundación Manuel Lillio, Tucumán, 77 pp.

Pike AW 1968. Recovery of helminth eggs from archaeological excavations, and their possible usefulness in providing evidence for the purpose of an occupation. Nature 219: 303304.

Reinhard K 1988 The cultural ecology of prehistoric parasitism on the Colorado Plateau as evidenced by coprology. Am J Phys Anthropol 77: 355-366.

Reinhard K, Gein PR, Callahan MM, Hevly RH 1992. Discovery of colon contents in skeletonized burial soil sampling for di- etary remains. J Archaeol Sci 19: 697-705.

Suriano DM, Navone GT 1994. Three new species of the genus Trihuris Roederer, 1761 (Nematoda: Trichuridae) from Cricetidae and Octodontidae rodents in Argentina. Res Rev Parasitol 54: 39-46.

Taek Han E, Mee Guk S, Lip Kim J, Jin Jeong H, Nam Kim S, Yil Chai J 2003. Detection of parasite eggs from archaeological excavations in the Republic of Korea. Mem Inst Oswaldo Cruz 98 (Suppl. I): 123-126.

Thienpont D, Rochette F, Vanparijs OFJ 1979. Diagnóstico de las Helmintiasis por Medio del Examen Coprológico, Janssen Research Foundation, Buenos Aires, 187 pp.

Walker PhL 1996. Integrative approaches to the study of ancient health: an example from the Santa Bárbara Channel area of Southern California. In A Perez Perez, Notes on Population Significance of Paleopathological Conditions, Fundación Uriach 1838, Barcelona, 97 pp. 
